\title{
Hygienizing Anaerobic Sludge using Vegetable Biomass, for Soil Fertilization
}

\author{
Saidelamine Abibe Mahadal ${ }^{1 *}$, Gino Roberto Gehling ${ }^{2}$ and Ana Dailda Felizardo ${ }^{3}$ \\ ${ }^{1}$ Assistant Professor, Universidade Rovuma, Department of Mathematics and Natural Sciences, Mozambique \\ ${ }^{2}$ Associate Professor, Universidade Federal do Rio Grande do Sul (UFRGS), Institute of Hydraulic Research, Brasil \\ ${ }^{3}$ University Assistant, Universidade Licungo, Department of Mathematics and Natural Sciences, Mozambique
}

*Corresponding Author: Saidelamine Abibe Mahadal, Assistant Professor, Universidade Rovuma, Department of Mathematics and Natural Sciences, Mozambique.

Received: July 22, 2019; Published: July 31, 2019

DOI: 10.31080/ASAG.2019.03.0594

\begin{abstract}
The generation of urban and industrial solid residues fit for recycling and reuse, calls for studies into the best ways to their reutilization. This paper describes a study that consisted of the combination of anaerobic sewage sludge and vegetable biomass ashes in order to obtain a hygienized solid biomass fit for agricultural soil fertilization. Sewage sludge contains pathogenic agents which are considered undesirable on agricultural soil. One of the best ways to reduce the pathogenic agents in sewage sludge is chemical stabilization which consists of the addition to it of a solid residue with a pH value equal or superior to 12 . The resulting mixture should maintain a minimum $\mathrm{pH}$ value of 12 for, at least, 2 hours and lime has been frequently used for this purpose. In this study the hygienization of sludge using ashes was tested. The process consisted of the mixture of a certain quantity of dried sludge with ashes in proportions of 30\%, 50\%, 100\% ashes/sludge. Samples were collected and sent to NSF Bioensaios' and Porto Belo's microbiologic analysis. They were tested for thermotolerant coliforms, total coliforms, helminht's eggs and salmonella which are used as indicators of biological contamination of sludge. The concentration of total coliforms, thermotolerants and salmonellas in the raw sludge was superior to the recommended values. Helminth's eggs were below the recommended limits. In the processed sludge, however, the thermotolerant coliforms were removed in all the samples treated with ashes: $92.5 \%$ removal in the $30 \%$ ash mixture; $98.3 \%$ removal in the $50 \%$ ash mixture and $99 \%$ in the $100 \%$ ash mixture. Sludge hygienization using ashes can be considered a viable stabilization process as it deactivates the pathogenic agents.
\end{abstract}

Keywords: Sludge; Hygienization; Ashes; pH; Biosolid

\section{Introduction}

The quantity of generated sewage sludge increases together with the increase of sewage collection and treatment services. In 2010, estimates indicated that between 150 and 220 thousand tons of dried sludge were generated in Brazil, when sewage treatment services were available only to $30 \%$ of the urban population [1].

The search for viable ways of sewage sludge final disposition is a global concern defined by Agenda 21 that includes the issue of "Environmentally safe handling of solid residues and sewage related issues" where non-generation, solid residues minimization, reuse and recycling maximization as well as environmentally adequate final disposition of waste was priorities [2].

In addressing this issue, the European Union formulated a directive, adopted by its member states, that forbids the deposit of recyclable residues in sanitary landfills since 2002. In the United
States, the same principle was established in 2004. Brazil had planned to implement a similar directive by 2014 however, the measure was postponed.

In many countries, studies on the use of biosolids on forest soils have been taking place proving the conditioning and fertilizing ability of these residues, according to the conditions of the soil and climates of North America, Europe, Asia and Africa, which boosted such studies, according to Harrison., et al. [3]; WANG., et al. [4]. This caused more than half of the sewage sludge generated in the United States and Western Europe to be used on farms, according to Gattie and Lewis [5] findings.

Considering studies conducted in North America and Europe where the use of sanitary sewage sludge as a fertilizer is not restricted, despite the long term permanence of pathogenic agents in the soil and the scarcity of studies conducted in tropical climate countries, questions on the necessity of restrictions to the application of sludge on soils in Brazil arise [6]. 
Currently, biologic sludge stabilization processes have been employed which consist of the use of natural biodegradation mechanisms that transform the sludge's most putrescible part. Chemical stabilization consists of the addition, to the sludge, of products that inhibit biological activity or oxidize organic matter. The alkaline way is the most used in which, a base, normally lime, is mixed with the sludge increasing its $\mathrm{pH}$ and destroying most of the pathogenic micro-organisms.

Sludge is an important source of organic matter, of micro and macro nutrients, increasing the soil's water retention ability (WRA) and its resistance to erosion. Sewage sludge final disposition is one of the major current urban environmental concerns. Like any other animal originated residue, sludge contains pathogenic microorganisms that reflect health state of the producing population.

The generation of residues by the cellulose and paper production industry has also been expressive, leading to environmental problems due to the big quantities of generated residues, approximately $48 \mathrm{t}$ for each $100 \mathrm{t}$ of cellulose produced [7]. Opting for the disposition of these residues in sanitary landfills is not viable due to the high cost of establishing and maintaining such facilities, as well as special care demanded by authorities, to avoid environmental contaminations.

Sewage sludge may be a source of potentially pathogenic bacteria as well as viruses, helminths, protozoa and fungi that may contaminate susceptible hosts. The awareness on pathogenic agents and their viability makes it possible to assess potential infection risks to human beings and other animals.

The quantity of pathogens in sewage sludge varies greatly and fundamentally depends on the population's socioeconomic conditions; sanitary conditions in the region; the presence of agro and food industry and on the sewage sludge treatment type [8]. The concentration of pathogenic agents may also vary chronologically which makes it difficult to compare results.

According to Fernandes [9], the objectives of sewage sludge stabilization processes are to reduce the pathogenic microorganisms and to inhibit, reduce or eliminate the emissions of volatile solids into the soil and, consequently, their odors' production potential which may attract vectors.

The extent to which viable helminth eggs are deactivated depends on the initial $\mathrm{pH}$ value and the sludge's stocking time. The bacteria in the sludge come from many sources, like the human and animal intestinal flora, the soil, the air and waste [10]. The transmission of the bacteria may be oral-fecal, through water and food.

This study aims at evaluating the efficiency of anaerobic ETE sludge hygienization using vegetable biomass to make it viable for use on agricultural soil, as well as its safe handling, safeguarding people's and environmental wellbeing.

\section{Materials and Methodology}

Source of ash and sludge samples

The ashes used in the sludge hygienization experiment come from the paper rand cellulose production process undertaken at VERACEL Company, located in the south of Bahia which encompasses the municipalities of Eunápolis, Canavieiros, Belmonte, Porto Seguro and Santa Cruz da Cabrália.

The company uses the Kraft method in its cellulose production process. The choice of this method is due to its efficiency and the fact that it is the most common in the industry.

The sludge under analysis is the digested anaerobic, from the sewage treatment at Serraria Treatment Facility located on the southern region of Porto Alegre, Ipanema, which is operated by the Municipal Water and Sewage Department, (DMAE in Portuguese). The Sewage Treatment Facility, (ETE in Portuguese), uses centrifuges to dehydrate the sludge and, to facilitate the separation between solids and liquids, it uses the cationic polymer, polyacrimalide, (PAM). The samples were collected from the containers, after dehydration with $80 \%$ humidity, between June and November 2017.

The study was conducted in Porto Alegre, Brazil. The Municipality of Porto Alegre comprises 496,7 Sq. Km and a population of $1,476,867$ inhabitants [11]. The climate is subtropical humid; there are four seasons, though, owing to its being located along a transitional zone, weather tends to vary frequently.

The annual average temperature is $19,5^{\circ} \mathrm{C}$; Between $10^{\circ} \mathrm{C}$ and $25^{\circ} \mathrm{C}$ in Autumn (March-June); Between $2^{\circ} \mathrm{C}$ and $20^{\circ} \mathrm{C}$ in Winter (June to September); between $15^{\circ} \mathrm{C}$ and $30^{\circ} \mathrm{C}$ in Spring (September to December) and varies between $25^{\circ} \mathrm{C}$ and $35^{\circ} \mathrm{C}$ in Summer (December-March). (Porto Alegre Municipal Government-Tourism, available online through www2.portoalegre.rs.gov.br/turismo/default.php?p_secao=260).

In relation to precipitation, winter and spring are the months with most precipitation. Humidity increases in the cold months due to cold currents.

\section{Sampling and sample preservation}

The ash samples were collected each 15 days, as advised by the CONAMA resolution 375/2006. Table 1 displays the dates the four raw samples were collected, which were kept in plastic containers that were, in turn, kept in ice inside Styrofoam boxes during transportation.

\section{Experimental protocol}

The experimental protocol consisted of the collection of the samples at ETE Serraria and forwarding them to certified laboratories for the planned analysis.

The sludge processing consisted of its mixing with ashes in the proportions of $30 \%, 50 \%$ and $100 \%$, in triplicate. For the propor- 
tion of $30 \%, 3000 \mathrm{~g}$ of sludge were mixed with $180 \mathrm{~g}$ of ashes; for $50 \%, 3.000 \mathrm{~g}$ of sludge were mixed with $300 \mathrm{~g}$ of ashes. And for the $100 \%$ proportion, $3000 \mathrm{~g}$ of sludge were mixed with $600 \mathrm{~g}$ of ashes. The processing was done in small quantities, in bench processing, making it easy to do manually. The mixture was made homogenous, samples were quartered and kept, after processing, in open plastic trays which were tagged and kept outdoors for 60 days, all covered by a plastic canvas.
After the 60 day incubation, the samples were sent to Bioensaios and Porto Belo laboratories for the analysis of the parameters mentioned earlier. Table 1 shows the collection calendar and the days the raw and treated samples were sent to the laboratories for analysis.

\begin{tabular}{|c|c|c|c|c|}
\hline \multirow{2}{*}{ Collection Date } & \multirow{2}{*}{ Sample } & \multirow{2}{*}{ Processing } & \multicolumn{2}{|c|}{ Analysis Dates } \\
\hline & & & Raw & Processed \\
\hline $7 / 12 / 2017$ & S1 & S1-W, S1-30 and S1-50 & $7 / 12 / 2017$ & $9 / 21 / 2017$ \\
\hline $7 / 26 / 2017$ & S2 & S2-W1, S2-30 and S2-50 & $7 / 26 / 2017$ & $10 / 18 / 2017$ \\
\hline $8 / 9 / 2017$ & S3 & S3-W, S3-30, S3-50 and S3-100 & $8 / 9 / 2017$ & $11 / 21 / 2017$ \\
\hline $8 / 30 / 2017$ & S4 & S4-W, S4-30, S4-50 and S4-100 & $8 / 30 / 2017$ & $11 / 21 / 2017$ \\
\hline
\end{tabular}

Table 1: Sample's collection, processing calendar.

\section{Samples nomenclature}

The first digit of the sample refers to the batch; the second to the percentage of ashes in relation to the solid sludge content; $\mathrm{W}$ stands for control.

The raw anaerobic sludge presented a neutral $\mathrm{pH},(7,1)$. During the mixing process of sludge with ashes in order to stabilize it, the sludge/alkalinizer mixture's $\mathrm{pH}$ increased; after some time, during the stabilization process, a decrease in the mixture's $\mathrm{pH}$ was noticed. To avoid an excessive drop in the $\mathrm{pH}$ value during the first 2 hours after mixing the sludge with ashes, a pH value higher than 12 is needed and this occurs when the alkalinizing element's concentration is increased. The dose of the alkalinizing substance, for the boost of the $\mathrm{pH}$ depends on many factors, such as the type of sludge (primary, activated sludge, etc.), its chemical compositions and the concentration of solids in the sludge [12].

\section{Lab analyses}

The chemical composition of the ash samples was analysed using the methodologies listed in Table 2.

The sludge characterization was done based on the National Environmental Committee Resolution (CONAMA in Portuguese) $\mathrm{N}^{\circ} 375$, of August 29th, 2006 which defines the criteria and procedures for the agricultural use of ETE generated sewage sludge and its derivates among other provisions. The analytic procedures follow the "Standard Methods for Examination of Water and Wastewater" recommendations from APHA/AWWA.

\begin{tabular}{|l|c|c|}
\hline \multicolumn{1}{|c|}{ Determination } & Methodology & Detection Limit \\
\hline Humidity, CRA & Gravimetry & - \\
\hline $\mathrm{pH}$ & Potenciometry $1: 5$ & - \\
\hline Organic carbon & Humid combustion & $0.01 \%$ \\
\hline $\mathrm{NTK}$ & Kjeldahl & $0.01 \%$ \\
\hline $\mathrm{CTC}$ & Normative instruction MAP 28/2007 & $0.1 \mathrm{cmol} / \mathrm{kg}$ \\
\hline Electric conductivity & Conductometry & - \\
\hline $\mathrm{B}$ & Dry digestion & $1 \mathrm{mg} / \mathrm{kg}$ \\
\hline $\mathrm{P}, \mathrm{K}, \mathrm{Na}, \mathrm{Ca}, \mathrm{Mg}$ & Nitric-perchloric wet digestion $/ \mathrm{ICP}-\mathrm{OES}$ & $0.01 \%$ \\
\hline $\mathrm{Al}$ & Nitric-perchloric wet digestion $/ \mathrm{ICP}-\mathrm{OES}$ & $0.02 \%$ \\
\hline $\mathrm{Pb}, \mathrm{As}, \mathrm{Se}, \mathrm{Zn}$ & Nitric-perchloric wet digestion $/ \mathrm{ICP}-\mathrm{OES}$ & $2 \mathrm{mg} / \mathrm{kg}$ \\
\hline $\mathrm{Cu}$ & Nitric-perchloric wet digestion $/ \mathrm{ICP}-\mathrm{OES}$ & $0.6 \mathrm{mg} / \mathrm{kg}$ \\
\hline $\mathrm{Cr}, \mathrm{Ni}$ & Nitric-perchloric wet digestion $/ \mathrm{ICP}-\mathrm{OES}$ & $0.4 \mathrm{mg} / \mathrm{kg}$ \\
\hline $\mathrm{Cd}$ & Nitric-perchloric wet digestion $/ \mathrm{ICP}-\mathrm{OES}$ & $0.2 \mathrm{mg} / \mathrm{kg}$ \\
\hline $\mathrm{Hg}$ & Wet digestion EPA 7471 cool steam & $0.01 \mathrm{mg} / \mathrm{kg}$ \\
\hline
\end{tabular}

Table 2: Methodologies used to analyse the ashes from VERACEL.

Source: VERACEL, 2015. 
To define the concentrations of ashes in sludge hygienization in dry weights, chemical stabilization researches using the proportions of $30 \%, 50 \%$ and $100 \%$ of ashes in relation to dry sludge content were conducted. Preliminary tests were done in order to determine the ash concentrations capable of maintaining the sludge's $\mathrm{pH}$ at, at least 12 , for a minimum period of 2 hours. Table 3 displays the preliminary $\mathrm{pH}$ results of the sludge and ash mixture samples, in the proportions described above. The raw anaerobic dewatered sludge's pH was 7,1.

\begin{tabular}{|l|l|l|}
\hline $\begin{array}{c}\text { Ashes' } \\
\text { concentration (\%) }\end{array}$ & $\begin{array}{c}\text { Instantaneous } \\
\text { pH }\end{array}$ & \multicolumn{1}{|c|}{$\begin{array}{c}\text { pH after 2 } \\
\text { hours }\end{array}$} \\
\hline 30 & 12,02 & 11,98 \\
\hline 50 & 12,20 & 12,10 \\
\hline 100 & 12,45 & 12,40 \\
\hline
\end{tabular}

Table 3: Sludge and ashes mixture's pH test results.
The table above shows that in all three concentrations, the ash and sludge mixture's $\mathrm{pH}$ values are above 12 at the beginning (Time Zero), and this value is retained for more than two hours in the $50 \%$ and $100 \%$ concentrations. The desirable minimum $\mathrm{pH}$ reading of 12,00 was not maintained during the necessary two hours in the $30 \%$ concentration, where there was a slight reduction to 11,98 .

For the total and thermotolerant coliforms' analysis, the most probable number procedure was applied to $100 \mathrm{~g}$ of dried matter; for the salmonelles, the salmonelle absence method was used to test $10 \mathrm{~g}$ of dried matter and, for helminths, the helminths' viable eggs counting.

\section{Results and Discussion}

The sewage sludge's microbiological characterization is very important for the control and identification of pathogenic microorganisms in it. Table 4 displays the microbiological parameters' results of the 4 raw samples, the averages and standard deviations.

\begin{tabular}{|l|c|c|c|c|c|}
\hline \multirow{2}{*}{\multicolumn{1}{c|}{ Parameter }} & \multicolumn{5}{c|}{ Samples } \\
\cline { 2 - 6 } & S1 & S2 & S3 & S4 & Average \pm DP \\
\hline Thermotol. Colif. NMP/g ST & 16.000 & 92.000 & 3.500 & 1.413 .610 & $381.277 \pm 689.331$ \\
\hline Tot colif. NMP/g ST & 11.000 & 241.960 & 241.960 & 1.600 .000 & $523.730 \pm 725.726$ \\
\hline Eggs/g helminth's viable ST & 0,56 & 0 & 0 & 0 & $0,14 \pm 0,28$ \\
\hline Salmonella sp NMP/10g ST & 35 & 32 & 107 & 70 & $61 \pm 35,18$ \\
\hline
\end{tabular}

Table 4: Raw sludge samples' pathogenic agents analysis results S1, S2, S3, S4, including averages and standard deviation.

The average coliforms' and salmonelles' values on Table 4, and the CONAMA 375/2006 orientations, disqualify the sludge for agricultural use. Thus, if there is any intention of using it on agricultural soil, it is necessary to hygienize it in order to lower the pathogens concentration levels into recommended proportions.
Table 5 shows the results obtained after the hygienization of the sludge using ashes, i.e., it shows the reduction of the pathogens from the raw sludge, control sludge and hygienized sludge, in different proportions.

\begin{tabular}{|l|c|c|c|c|c|}
\hline \multicolumn{1}{|c|}{ Types of sludge or biosolids } & Raw sludge & Control sludge & $\mathbf{3 0} \%$ sludge & $\mathbf{5 0}$ \% sludge & 100 \% sludge \\
\hline Thermotolerant coliforms (NMP/gST) & 381.277 & $1.464,25$ & 28,63 & 0,68 & 0,30 \\
\hline Salmonelles (NMP/10gST) & 61 & 0,15 & 0,075 & 0,0 & 0,0 \\
\hline Helminth's eggs (eggs/gST) & 0,14 & 0,04 & 0,0 &, 0 & 0,0 \\
\hline
\end{tabular}

Table 5: Level of reduction of pathogens in the hygienized sludge.

As shown by the table above, the following were the thermotolerant coliform average values in $\mathrm{NMP} / \mathrm{g}$ ST in the sludge under analysis: $381.277,5,1.464,2,28,6,0,6$ and 0,3 for the raw, control, and hygienized sludge with $30 \%, 50 \%$ and $100 \%$ of ashes, respectively (Figure 1). Analyzing figure 1, a difference among the averages is noticeable, however, such difference cannot be statistically tested due to the samples variability.

Figure 1 shows the reduction of the thermotolerant coliforms in the hygienized sludge to the levels recommended by the CONAMA $376 / 2006$ resolution, which were stipulated to be $1.000 \mathrm{NMP} / \mathrm{g}$.
MS, resulting in class A sludge. The control sludge, because of the 60-day incubation humidity reduction process, presented a thermotolerant coliform drop consistent with class B sludge, according to the 375/2006 CONAMA resolution.

In terms of percentage, in all ash treatments, therhermotolernt coliforms were removed after hygienization: 92,5\% removal in the hygienization with $30 \%$ ashes; $98,3 \%$ removal in the hygienization using $50 \%$ ash and $99 \%$ with $100 \%$ ash. In a study conducted by PROSAB on the efficiency of liming as a sludge disinfection method, 


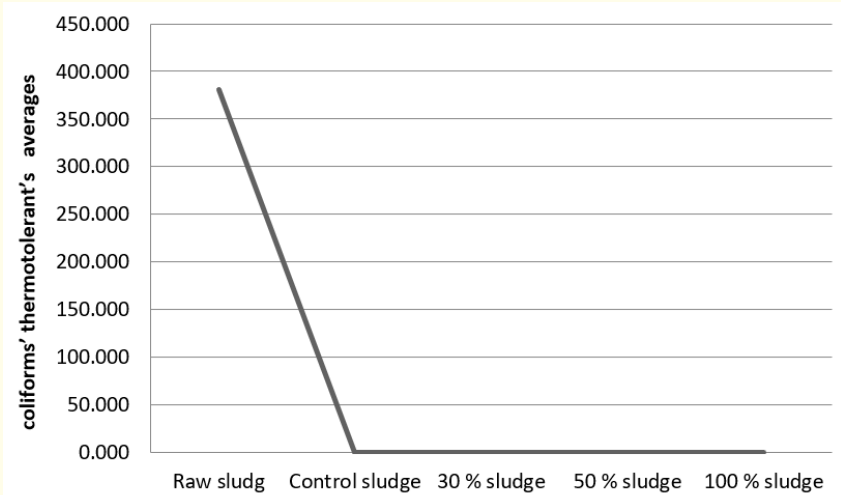

Figure 1: Thermotolerant coliforms' concentration in the sludge and biosolids.

proportions of $30 \%, 40 \%$ and $50 \%$ of lime in relation to dry sludge were used and, as a result, $100 \%$ of the pathogens were removed.

Passamani, Keller and Gonçalves (2002), in a study on sludge hygienization using $30 \%$ of hydrated lime, reported a growth of coliforms in 30 days of lime-sludge stocking, followed by a $\mathrm{pH}$ value decrease. In the liming using $40 \%$ hydrated lime, the authors reported that the same behaviour was observed after 60 days but using dosages of 50 and 60 percent lime, there was no coliforms growth.

The average salmonelles spp value in the raw sludge was 61 $\mathrm{NMP} / \mathrm{g}$ ST. For all the proportions of ashes used in the sludge hygienization process, there was a $99,8 \%$ reduction of salmonellas spp in the biosolids. The resulting values were submitted to variance analysis and considerable differences were noticed by $\mathrm{F}$ test, between the raw sludge (group 2), the control sludge and the biosolids (group 1). Table 6 presents the average salmonellas spp values of the sludge under analysis.

\begin{tabular}{|l|c|c|}
\hline Groups & $\mathbf{1}$ & $\mathbf{2}$ \\
\hline Ash 30 & 0 & - \\
\hline Ash100 & 0 & - \\
\hline Ash 50 & $0,075 \pm 0,15$ & - \\
\hline Control & $0,15 \pm 0,17$ & - \\
\hline Raw & - & $61 \pm 35,18$ \\
\hline
\end{tabular}

Table 6: Salmonellas spp. Values and DP in the different sludges and biosolids.

On the Table 6 data, it is noticeable that, compared to the control sludge, the addition of ashes to the sludge, considerably reduces the salmonellas spp content. Figure 2 displays the behaviour of the salmonellas spp in the sludge and biosolids from Serraria ETE.

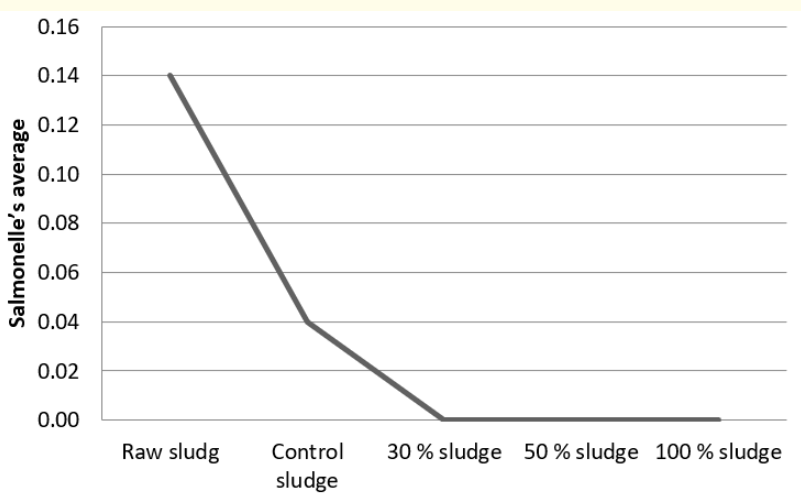

Figure 2: Salmonellas spp's behaviour in the sludge and biosolids.

The removal levels found are similar to those achieved by PROS$\mathrm{AB}$ where ETE sludge was hygienized through liming. According to Fernandes., et al. [13], the said study on the efficiency of liming as a sludge disinfection method, tested 30,40 and 50 percent doses in relation to the sludge's dry weights, and achieved $100 \%$ salmonelles spp removal, for all concentrations. Of all the 4 raw samples collected, only the first one had helminth eggs. The following average helminth's egg's values per gram, (eggs/g.ST), were found: $0,14,0,04,0,00,0,00$ and 0,00 in the raw sludge, control and hygienized with $30 \%, 50 \%$ and $100 \%$, respectively. Figure 3 shows the behaviour of the helminth eggs. The variation analysis, through $\mathrm{F}$ test, showed no existence of relevant differences amongst the results [14-17].

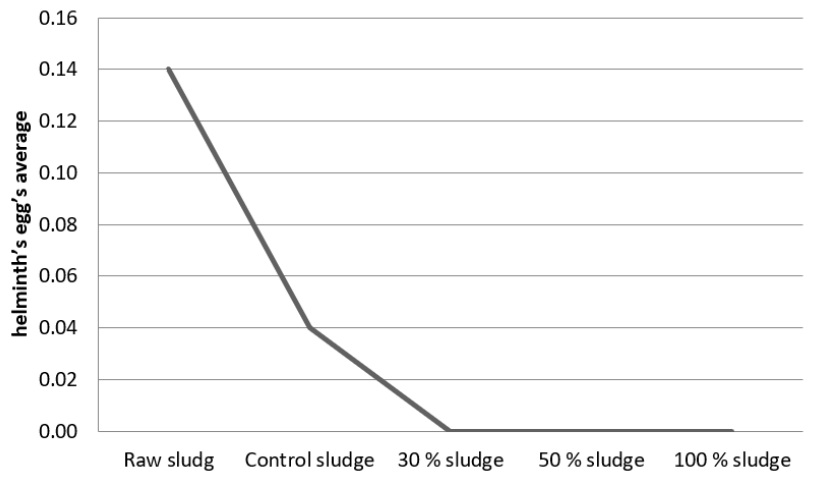

Figure 3: Behaviour of the helminths's eggs in sludge and biosolids.

\section{ANOVA test}

In order to verify the similarity of the results, ANOVA statistic tests were conducted using SPSS software, version 18.

The differences between the averages were determined using the Turkey-Krame test. All the conclusions were based on a significance level of $\alpha-0,05$. Table 7 shows the ANOVA data for the parameter pathogenic agent. 


\begin{tabular}{|c|c|c|c|c|c|c|c|c|c|}
\hline & & $\begin{array}{c}\text { Sample } \\
\text { size }\end{array}$ & Average & $\begin{array}{l}\text { Standard } \\
\text { deviation }\end{array}$ & $\begin{array}{l}\text { Standard } \\
\text { error }\end{array}$ & Average $\mathrm{Tr}$ & st Interval & Minimum & Maximum \\
\hline \multirow{6}{*}{$\begin{array}{l}\text { Thermo- } \\
\text { tolerant } \\
\text { coliforms } \\
\text { NMP }\end{array}$} & Raw & 4 & 381277,50 & 689331,89 & 344665,94 & $-715603,36$ & 1478158,36 & 3500,00 & 1413610,00 \\
\hline & Control & 4 & 1464,25 & 2145,47 & 1072,74 & $-1949,68$ & 4878,18 & 40,00 & 4600,00 \\
\hline & Ashes 30 & 4 & 28,63 & 54,26 & 27,13 & $-57,71$ & 114,96 & 0,30 & 110,00 \\
\hline & Ashes 50 & 4 & 0,68 & 0,75 & 0,38 & $-0,52$ & 1,87 & 0,30 & 1,80 \\
\hline & Ashes 100 & 2 & 0,30 & 0,00 & 0,00 & 0,30 & 0,30 & 0,30 & 0,30 \\
\hline & Total & 18 & 85060,27 & 332266,14 & 78315,88 & $-80171,80$ & 250292,33 & 0,30 & 1413610,00 \\
\hline \multirow{6}{*}{$\begin{array}{l}\text { Total } \\
\text { coliforms } \\
\text { NMP }\end{array}$} & Raw & 4 & 523730,00 & 725726,72 & 362863,36 & $-631063,16$ & 1678523,16 & 11000,00 & 1600000,00 \\
\hline & Control & 4 & 61049,25 & 120606,20 & 60303,10 & $-130862,13$ & 252960,63 & 40,00 & 241957,00 \\
\hline & Ashes 30 & 4 & 214,43 & 357,41 & 178,70 & $-354,29$ & 783,14 & 0,30 & 745,00 \\
\hline & Ashes 50 & 4 & 817,53 & 1632,98 & 816,49 & $-1780,92$ & 3415,97 & 0,30 & 3267,00 \\
\hline & Ashes 100 & 2 & 0,30 & 0,00 & 0,00 & 0,30 & 0,30 & 0,30 & 0,30 \\
\hline & Total & 18 & 130180,30 & 378131,84 & 89126,53 & $-57860,24$ & 318220,84 & 0,30 & 1600000,00 \\
\hline \multirow{6}{*}{$\begin{array}{l}\text { Viable } \\
\text { eggs } \\
\text { eggs/g ST }\end{array}$} & Raw & 4 & 0,14 & 0,28 & 0,14 & $-0,31$ & 0,59 & 0,00 & 0,56 \\
\hline & Control & 4 & 0,04 & 0,07 & 0,04 & $-0,08$ & 0,15 & 0,00 & 0,14 \\
\hline & Ashes 30 & 4 & 0,00 & 0,00 & 0,00 & 0,00 & 0,00 & 0,00 & 0,00 \\
\hline & Ashes 50 & 4 & 0,00 & 0,00 & 0,00 & 0,00 & 0,00 & 0,00 & 0,00 \\
\hline & Ashes 100 & 2 & 0,00 & 0,00 & 0,00 & 0,00 & 0,00 & 0,00 & 0,00 \\
\hline & Total & 18 & 0,04 & 0,13 & 0,03 & $-0,03$ & 0,11 & 0,00 & 0,56 \\
\hline \multirow{6}{*}{$\begin{array}{l}\text { Salmonelle } \\
\text { sp NMP/g } \\
\text { ST }\end{array}$} & Raw & 4 & 61,00 & 35,19 & 17,59 & 5,01 & 116,99 & 32,00 & 107,00 \\
\hline & Control & 4 & 0,15 & 0,17 & 0,09 & $-0,13$ & 0,43 & 0,00 & 0,30 \\
\hline & Ashes 30 & 4 & 0,00 & 0,00 & 0,00 & 0,00 & 0,00 & 0,00 & 0,00 \\
\hline & Ashes 50 & 4 & 0,08 & 0,15 & 0,08 & $-0,16$ & 0,31 & 0,00 & 0,30 \\
\hline & Ashes 100 & 2 & 0,00 & 0,00 & 0,00 & 0,00 & 0,00 & 0,00 & 0,00 \\
\hline & Total & 18 & 13,61 & 29,97 & 7,06 & $-1,30$ & 28,51 & 0,00 & 107,00 \\
\hline
\end{tabular}

Table 7: ANOVA data for the parameter pathogenic agents.

\section{Conclusion}

- The vegetable biomass ashes from VERACEL Company show accentuated alkaline features which make them adequate for sludge hygienization;

- The microbiologic results of ETE's raw anaerobic sludge show thermotolerant coliform's concentrations above the levels recommended by CONAMA 375/2006 resolution thus requiring an hygienization process before it can be used in agriculture.

- The hygienization of sludge using vegetable mass ashes in the concentrations of $30 \%, 50 \%$ and $100 \%$, reduces the microorganism content to levels below $103 \mathrm{NMP} / \mathrm{g}$ ST, yielding class A biosolids which, according to CONAMA 375/2006 and EPA norms, may be used in agriculture;

- The mixture of sludge and ashes yields a biosolid that is appropriate for use on agricultural soil.
- The control sludge did not show a coliform concentration lower than $103 \mathrm{NMP} / \mathrm{g}$ ST, which shows that the dewatering process by itself does not lead to microorganisms content reduction to the recommended levels;

- In the chemical stabilization of sludge using virgin lime, an exothermic reaction occurs plus a temperature rise. During the sludge processing discussed in this paper, naturally, there was no exothermic reaction since the pathogen's reduction was due to an increase of ash/sludge mixture's $\mathrm{pH}$.

\section{Acknowledgement}

The authors would like to thank CNPq for the scholarship granted within the Mozambique/Brazil cooperation framework; Calouste Gulbenkian Foundation for the research grant; Renata Maltz at VIDA Co. for the cellulose industry residues used in the study; Adriana Cechin and Lucimara Comunello and other DAE staff members for their availability and for offering the sludge analysed in the study; NSF-Bioensaios and Porto Belo lab personnel for analyzing the samples. 


\section{Bibliography}

1. Pedroza MM., et al. "Sewage Sludge Production and Treatment: a review". Revista Liberato, Novo Hamburgo 11.14 (2010): 147-157.

2. Von Sperling M., et al. "Sewage sludge: characteristics and production". In: ANDREOLI, C.V.; SPERLING, M.; FERNANDES, F. (Ed.). Sewage sludge: treatment and final disposition. Belo Horizonte: Department of Sanitary and Environmental Engineering UFMG, (2001): 17-67.

3. Harrison R., et al. "Long-term effects of heavy applications of biosolids on organic matter and nutrient content of a coarsetexture forest soil". Forest Ecology and Management, Amsterdam 66 (1994): 165-177.

4. Wang P., et al. "Short-term effects of nutrient compensation following whole-tree harvesting on soil and soil water chemistry in a young Norway spruce stand". Plant and Soil 336 (2010): 323-336

5. Gattie DK and Lewis DL. "A high-level disinfection standard for land-applied sewage sludges (biosolids)". Environmental Health Perspectives, Research Triangle Park, NC 112.2 (2004): 126-131.

6. Pires AMM and Andrade CA. Sewage Sludge dose recommendation: the nitrogen issue. Jaguariúna: Embrapa Meio Ambiente (2014): 7 .

7. Bellote AFJ., et al. "Ecological implications of using cauldron ashes and cellulose residues in Eucalyptusgrandis plantations". In: Seminar on the use of industrial and domestic residues in forests, 1994, Botucatu. [Anais]. Botucatu: Agronomic Sciences Faculty (1994): 167-187.

8. Andraus S., et al. "Pathogenic Agents: Enteryc Bateria". In: ANDREOLI, C.V.; LARA, A.I.; FERNANDES, F. (Org) Biosolids Recycling: turning problems into solutions. Curitiba: Sanepar, Finep (1999): 126-155.

9. Fernandes F. "Stabilization and Hygienization of Biosolids". In BETTIOL, W., CAMARGO, O.A. Environmental Impact of sewage sludge agricultural use. Jaguariúna. Embrapa Meio ambiente, (2000): 45-68.

10. Silva FC., et al. "Sewage sludge effects on the fertility of a red argisoil cultivated with sugarcane". Brazilian Agronomy Research Brasilia 36.5 (2001): 831-840.

11. IBGE. Demographic Census, Porto Alegre Municipality Data. Rio de Janeiro: Brazilian Geography and Statistics Institute Foundation, (2015).
12. WPCF. "Sludge stabilization-Manual of practice FD-9". Prepared by task force on sludge stabilization. Washington (1985).

13. Fernandes, F., et al. "Evaluation of sludge management alternatives at ETE”. In: C.V. ANDREOLI; M.V.; SPERLING, M.; FERNANDES, F (Ed.). Sewage sludge: Treatment and final disposition. Belo Horizonte: Department of Environmental and Sanitary Engineering, UFMG (2001): 299-317.

14. Gasi TMT and Rossin AC. "Removal of index microorganisms and pathogens in UASB reactor operating on domestic sewers". In: Brazilian Congress of Environmental Sanitary Engineering. Rio de Janeiro, RJ. Anais. Natal: Abes, (1993).

15. Pinto MT. "Sludges' Hygienization”. In: ANDREOLI, C.V.; SPERLING, M.V.; FERNANDES, F (Ed.). Sewage sludge: treatment and final disposition. Belo Horizonte: Department of Sanitary and Environmental Engineering UFMG (2017): 159-188.

16. Feachem RG., et al. "Sanitation and disease: health Aspects of excreta and wastewater management". New York: John Wiley, (1983): 501.

17. Rocha ALCL. "Hygienization of anaerobic sewage sludge by alkaline means: case study of ETE Lages, Aparecida de Goiânia - GO”. 2009. 118f. Masters Dissertation - Goiás Federal University, Goiânia, (2009).

\section{Volume 3 Issue 8 August 2019}

(C) All rights are reserved by Saidelamine Abibe

Mahadal., et al. 